\title{
Coordinating the Arm Swing with the Pivot: Nuclear Deterrence, Stability and US Strategy in the Asia-Pacific
}

\section{Andrew Futter and Benjamin Zala}

\begin{abstract}
United States foreign policy towards the Asia-Pacific region is set to be fundamentally altered by two developments in Washington's defence policy. The first, much publicised change is the announcement of a so-called pivot towards the region in terms of overall defence strategy. The second, largely going unnoticed but occurring at roughly the same time, is a move towards a far greater role for advanced conventional weaponry in the US defence posture and the subsequent effect on extended nuclear deterrence thinking and practice. This article analyses the interaction of these two trends and discusses a central tension between short-term and long-term challenges for the United States arising from this situation, and suggests that contrary to current developments, either a freeze in the deployment of a number of advanced conventional weapons programmes or a return to a strategy underpinned by traditional notions of nuclear deterrence may provide the most productive basis for future regional security and stability.
\end{abstract}

Keywords Asia-Pacific, US defence policy, nuclear deterrence, stability, conventional weapons, missile defence

\section{Introduction}

Since the end of the Cold War, two fundamental dynamics have been slowly impacting US strategic thinking and policy. The first is a gradual shift towards Asia and the Pacific as the key locus of the most pressing challenges and opportunities for the United States. A decade of involvement in the Middle East may have clouded this, but announcements and decisions taken by President Barack Obama appear to have placed the US back on the track first begun by Presidents George HW Bush and Bill Clinton in the early 1990s. The second dynamic, and one that is perhaps slightly less pronounced, has been a gradual change in the way in which the US approaches the issue of nuclear deterrence. In this respect, the last two decades have seen a gradual shift in focus towards advanced conventional military forces to enhance and augment nuclear weapons as the central component of US policy. Intriguingly therefore, the US 'pivot' towards the Asia-Pacific ${ }^{1}$ comes at the same time that this region, especially the Northeast and East - with a mixture of new military challenges from North Korea and China combined with nations that have traditionally relied upon a US security

\footnotetext{
${ }^{1}$ The Asia-Pacific region is taken to include Northeast Asia, Southeast Asia and Oceania (and to a lesser extent Russia and South Asia); or the area encompassed between China, Japan and Australia. The whole notion of the 'pivot' of course assumes that the United States itself is included in the region (hence using the term Asia-Pacific here).
} 
Accepted (pre-copy-edited) version for The Pacific Review.

guarantee, such as Japan, South Korea and Taiwan - is becoming more rather than less reliant upon traditional (nuclear) notions of security and stability.

The result is that it is far from clear that a new 'nuanced' US approach to defence and deterrence in the region will be commensurate with the dynamics of this complex regional balance, or even whether such a policy will help to underpin US aims in the region more widely. Specifically, the way in which the US seeks to mitigate this cleavage between North Korea/ China and the 'status quo' traditional US allies in the region is likely to have far reaching consequences for the 'pivot' eastwards and for the US-led nuclear non-proliferation agenda more broadly. The result seems likely to be a set of difficult questions regarding the relative importance of dealing with North Korea vis-à-vis managing relations with China, while at the same time convincing other regional actors of the viability of a continuing US security guarantee.

This article proceeds in three sections; the first looks more closely at the two key dynamics that have come together to create the current strategic environment, namely the economic, military and political drivers behind the US pivot towards the Asia-Pacific, and the changing nature of US security and deterrence thinking over the past two decades, particularly as it relates to the region. The second explains why this mixture of geographical repositioning and changing deterrence thinking presents a complex set of challenges for the Northeast of the region - essentially the shortterm challenge of managing a nuclear North Korea and the longer term implications of a rising China - and the way that both are impacted by existing US alliances. The third section considers the ever-more complex set of policy options and strategic scenarios facing US planners, and examines how key geopolitical decisions that will have to be taken in Barack Obama's second term in office will impact the future of strategic relations in the Asia-Pacific and the wider regional nuclear non-proliferation agenda.

\section{Changing Focus, Altering Policy: Pivoting Eastwards and Shifting Deterrence Thinking}

It is now widely accepted that the $21^{\text {st }}$ Century is likely to be characterized by, if not the 'Asian century', then at least a greater role for Asian powers in the global order (See Mahbubani 2008; Tellis 2010; Florini 2011); growing populations, technological progress and rapidly expanding economies are all shifting the international focus eastward and away from traditional Transatlantic centres of power (Dunn \& Zala 2014). It is therefore not surprising that the United States is moving to place the region at the heart of its international strategy as it looks to reverse the narrative of 'inevitable' decline in relative power terms. Nevertheless, and while the 'pivot' offers many 
Accepted (pre-copy-edited) version for The Pacific Review.

opportunities, it also offers a number of key challenges. Amongst the most pressing of these challenges is the future of the US role as a regional power balancer - primarily pursued through a series of bilateral security guarantees - especially as the United States seeks to alter its own defence thinking in light of regional challenges from North Korea and China. Balancing these requirements looks to be an increasingly complex task. While short-term defence objectives, such as using advanced conventional weaponry to counter threats from North Korea, are favoured over addressing questions of long-term stability with key actors such as China, Washington's pivot towards the Asia-Pacific will remain a potentially dangerous one.

\section{The Pivot}

While the US focused its attention primarily on Europe and Russia during the Cold War ${ }^{2}$, and has more recently found itself engaged in a decade of fighting in the Middle East, policymakers have always been aware of the strategic importance of 'the East'. Nevertheless, it is only now, with the US involvement in Afghanistan and Iraq coming to an end, and a European continent that appears to have found a durable peace, has the US been able to fully begin the geographical switch. Perhaps because of this, it is unsurprising that it has been under Barack Obama that the US has really begun its 'pivot' towards the region: “as we end today's wars, I have directed my national security team to make our presence and missions in the Asia-Pacific a top priority" (United States Department of Defense 2012: 2).

There are a number of reasons why the United States has become increasingly preoccupied with the threats and opportunities that it sees in the Asia-Pacific; threats and opportunities that are economic, military and political. The growing importance of the region for US policy is perhaps best outlined by the Obama administration's official announcement:

US economic and security interests are inextricably linked to developments in the arc extending from the Western Pacific and East Asia into the Indian Ocean region and South Asia, creating a mix of evolving challenges and opportunities. Accordingly, while the U.S. military will continue to contribute to security globally, we will of necessity rebalance toward the Asia-Pacific region. Our relationships with Asian allies and key partners are critical to the future stability and growth of the region. We will emphasize our existing alliances, which provide a vital foundation for Asia-Pacific security (Ibid).

It is perhaps for this reason that decision makers in Washington are increasingly less focused on the forward projection of power in regions such as the Middle East and Central Asia (the current crises

\footnotetext{
${ }^{2}$ Despite the wars in Korea and Vietnam, the majority of Washington's strategic focus centred on the USSR as its only serious rival and major adversary and key European states as its most important allies. Even the rapprochement with China in the early 1970s had more to do with dividing the Soviet Union from its largest ally than anything that was happening in the Asian region.
} 
in Syria and with Iran notwithstanding). Instead, a return to a focus on the Asia Pacific region heralds for many, a chance to neuter suspicions of the relative decline of US global influence before it's too late.

The overwhelming driver of this change in focus is economic. The Asia-Pacific region now accounts for roughly $36 \%$ of global exports and $34 \%$ of global imports and Asian and Pacific trade grew faster than the world average for 2005-2010 (United Nations Economic and Social Commission for Asia and the Pacific 2011). The then US Secretary of State Hilary Clinton, stated in 2011 that "In a time of scarce resources, there's no question that we need to invest them wisely where they will yield the biggest returns, which is why the Asia-Pacific represents such a real 21stcentury opportunity for us" (Clinton, 2011: 62). Many commentators are now anticipating the military and strategic dimensions of this shift in global economic weight (see Holslag, 2010; Wesley 2011; Till, 2012). China and India are both undergoing large-scale military modernisation programmes and this is in turn driving other states across the region to do the same (Cordesman, 2011). This not only has political and strategic consequences for Washington, but as the largest global supplier of conventional weapons, this has economic consequences for the United States as it struggles to build the foundations of its economic recovery. In terms of being a market for conventional arms transfers, the Asia Pacific region is growing in importance for the United States. Between 2006 and 2010, three of the US' top five recipients were located there (South Korea, Australia and Japan) and the region accounts for a higher percentage of global sales (at 44\%) than both the Middle East (28\%) and Europe (19\%) (Boulanin, 2011: 273).

Militarily, the Asia-Pacific is also home to two of the two most prominent military challenges faced by the United States; namely the short term concerns regarding the North Korean nuclear programme, and the longer term question of Chinese ascendency (discussed below in more detail). The rise of China as a military - as well as political and economic - force, and the implications that this has for the regional military balance and stability, is the fundamental reason why US policymakers are desperate to re-engage with the 'east' (The Economist, 7 April 2012). Strategically, however, and at the same time that the Asia-Pacific may be becoming more important for the US, Xiaosong Tang argues that "US power is no longer as clear-cut as it once was" in the region (2011: 2). Indeed, Tang suggests that there are three main reasons for this; the declining dependence of the region's economies on the US, "question marks over the political will of the United States, and its ability, to continue underwriting the region's security", and "the relative decline of US soft power in the region" (Ibid). Against this backdrop of the 'rise of the East' in economic and political terms is what some think of as the relative decline of the United States in terms of global power. No matter which side one takes in this debate, what is almost inevitable is 
that the vast disparity in power between the United States and all other possible peer rivals that has characterised the post-Cold War unipolar era is set to, at the very least, decrease. ${ }^{3}$ The wars in Afghanistan and Iraq have demonstrated the limits of US hard power. Washington has been unable to achieve its stated objectives in either case. These limitations have also been on display in soft power terms as the international support, at least initially present for the invasion of Afghanistan, has gradually receded and accounted for relatively little in terms of troops on the ground. This sense of a loss of soft power appeal has been heightened by the global financial crisis. As Xiasong Tang points out:

Although it remains the dominant power, the geopolitical, security and economic factors that traditionally have underpinned US power and influence are changing. In order to maintain its dominance, Washington must begin to adjust its foreign policy and diplomatic strategy in the region to accommodate China's rising influence (Tang, 2011: 1).

Symbolically, key administration officials have delivered high-profile speeches on the increasing importance of the Asia-Pacific region for US defence and trade policies (Donilon 2012; Biden 2013; Hagel 2013) and President Obama has taken particular care to emphasize the growing importance of Asia's 'other' giant, India saying that the US-Indian relationship will be "a defining partnership of the century ahead" (quoted in Biden 2013). All of this is underpinned by the strategic guidance document issued by the Department of Defense in January 2012, Sustaining US Global Leadership: Priorities for 21st Century Defense, which outlined the need to make "the necessary investments to ensure that we maintain regional access and the ability to operate freely in keeping with our treaty obligations" in the region (Department of Defense 2012: 2).

In terms of actual policy change, the pivot so far has a mixed record. While some have grown increasingly skeptical about how much difference this is actually making to US defence policy and force deployments, there are some signs of seriousness from Washington. Firstly, at a time when it is pulling troops out of bases in Germany (Shanker and Erlanger 2012), President Obama flew to Australia in late 2011 to announce the opening of a new US marine base in Darwin in the north of Australia (Hartcher 2011). Secondly, this has been followed by training agreements and high-level defence meetings with allies such as Philippines, Malaysia, and Thailand.

\section{Nuanced US deterrence}

\footnotetext{
${ }^{3}$ Even those such as Michael Cox (2012) who are less convinced by the US decline thesis admit that an evening out of global power disparities is highly likely over the coming decades. Stephen Brookes and William Wohlforth (2008) who argue that US primacy is likely to endure for some time yet represent a minority view in this debate, a position that has been (rightly or wrongly) further entrenched by the global financial crisis.
} 
The second important dynamic to consider is the gradual diversification in US defence and deterrence thinking that has been underway since the end of the Cold War. In this regard, and while conventional forces have always played a key role in strategic defence and deterrence, there has been a noticeable qualitative change in the past 20 years. In particular it has been the growth of what has become termed a 'new strategic triad' consisting of both offensive and defensive advanced conventional programmes, advances in command, control and more traditional offensive nuclear retaliatory strike options (See McDonough, 2006). As David McDonough points out:

The new triad represents a complex and potentially contradictory effort to reduce American self-deterrence by de-emphasizing the role of nuclear weapons through an expansion of non-nuclear components in US deterrence calculus, while simultaneously attempting to modify American nuclear forces to play a more tailored deterrent role against potential adversaries (Ibid: 11).

Over a number of years, the capabilities of these systems have been slowly impacting the way in which the US thinks about deterring nuclear threats.

The moves towards a more diversified US posture can be traced back to the early 1990s as policy makers began to question the central underpinnings of MAD in a new world order no longer dominated by the Cold War standoff with the Soviet Union. Indeed, it was the growing concern about North Korea - in the wake of the intelligence shock of the extent of Iraq's WMD programme discovered after the first Gulf War - that really began to change the debate in the US (Cirincione 2000). The period since has seen a slow coming together of a new type of nuclear threat (horizontal proliferation rather than superpower arms racing) and the technology needed to counter this (ballistic missile defence, long-range conventional missile programmes, and advanced monitoring capabilities) (See Futter, 2013; McDonough, 2006).

As the 2010 US Nuclear Posture Review points out, these new capabilities have been largely accepted as essential components of US strategic thinking by the Obama administration:

Although nuclear weapons have proved to be a key component of U.S. assurances to allies and partners, the United States has relied increasingly on non-nuclear elements to strengthen regional security architectures, including a forward U.S. conventional presence and effective theatre ballistic missile defenses. As the role of nuclear weapons is reduced in U.S. national security strategy, these non-nuclear elements will take on a greater share of the deterrence burden (United States Department of Defense, 2010: xiii).

This has been driven in part by President Obama's emphasis on renewing the nuclear abolition agenda as laid out in a speech in Prague in 2009 (See Obama, 5 April 2009), and by his wider desire to reduce the role of nuclear weapons in US defence and deterrence thinking (see Futter \& Zala, 2013). The latter involves a significant shift in the US defence posture mainly based around the continued development, despite some rhetoric to the contrary, of missile defence (albeit with a 
greater focus on theatre rather than national systems) and the increasing development of long-range conventional missile systems - in particular the Prompt Global Strike (PGS) programme (Ibid). While the administration's scrapping of the European 'third site' component of the US ballistic missile defence (BMD) plan was hailed as a scaling back of the programme, this simplistic reading obscured the extent to which the current plan is in fact one of greater flexibility and scope than the previous George W Bush administration (See Zadra, 2010; Futter, 2012a). The PGS system, essentially an attempt to create a capability for fast precision missile strike across the globe using conventional warheads, has attracted increasing support in defence policy circles in Washington (despite relatively small funding reductions over the past two years as part of wider Pentagon cuts) (Woolf, 13 February 2012). One of the effects of making such a clear link between these conventional weapons programmes, both offensive and defensive, and the goal of a nuclear weapons-free world, is that despite short term technical setbacks or funding issues, their role in the US defence posture over the longer-term can only become greater as progress (no matter how minor or how slow) in nuclear reductions continues over time.

In terms of the Asia-Pacific region specifically, plans have been underway for some time to augment the traditional 'hub and spoke' system of bilateral - largely nuclear - guarantees that predominated US strategic thinking during the Cold War (on this see Blair \& Hanley 2010). This strategy, which placed offshore extended nuclear deterrence as the centrepiece has slowly altered since the US removed its forward-deployed tactical nuclear weapons from the region in the early 1990s (while similar munitions remained in NATO Europe) (See Bush, 2011). Indeed, the February 2010 Ballistic Missile Defense Review (BMDR) report stated that:

... the United States will pursue a phased adaptive approach within each region that is tailored to the threats unique to that region, including their scale, the scope and pace of their development, and the capabilities available and most suited for deployment (United States Department of Defense 2010a: 23).

US BMD assets in the region for example already include cooperation on the Aegis SM-3 system with Japan, while collaborative programmes and discussions are also underway with a number of other key US partners in Asia (Ibid: 32-33). It is now being widely reported that Washington is planning "a major expansion of missile defenses in Asia" as part of the strategic shift towards the region (Entous \& Barnes, 23 August 2012). This is only likely to expand as the extent of the 'pivot' increases and the United States becomes more and more focused on its interests in the region.

Taken together these dynamics represent an interesting strategic equation: the US is moving into a region which still appears wedded to traditional Cold War conceptions of security (at least as it relates to nuclear weapons) at the same time as the US is seeking to alter its deterrence thinking 
Accepted (pre-copy-edited) version for The Pacific Review.

away from Cold War conceptions; both of these dynamics look set to produce divergent strategic pressures in the region. As Washington attempts to move beyond the inherent vulnerability in traditional deterrence relationships by relying much more heavily on advanced conventional weaponry - both to defend against and even pre-emptively knock out missile attacks from potential adversaries - the Asia-Pacific region may prove to be the hardest test for this new approach. In particular, as new advanced military technologies aimed at addressing immediate threats from North Korea are increased, the potential for the same technology to cause long-term instability in the US-Sino relationship will become an ever-greater concern.

\section{Nuclear Challengers and Strategic Alliances: US Policy and the Complex East Asian Nuclear Balance}

The changing dynamics alluded to above raise a number of interesting issues that will need to be addressed as part of the US 'pivot' towards the Asia-Pacific, and these can be split broadly into two parts. First is the question of how this new strategy will help to address the nuclear challenge from North Korea, a key priority for short term regional stability, while at the same time seeking to prepare for the longer term challenge of a rising China and of how Sino-US relations can avoid the tension and conflict predicted by power transition theory (see Copeland 2000). The second set of challenges relates to how this can be balanced alongside retaining the credibility of the traditional US security guarantee (based largely on offshore nuclear deterrence), in order to discourage a renewed militarisation of the region driven by concerns over North Korea and over the longer-term, China, on the part of traditional US allies. While both of these dynamics are largely confined to the Northeast and East of the region, their interlinked and co-constitutive nature means that they will inevitably have significant knock-on effects for the wider region.

\section{Short and long term challenges: North Korea and China}

While the main motivation for Washington's return to the Asia-Pacific might be economic, the region does contain two centrally important strategic challenges for US policymakers. In the shortterm the Korean Peninsula remains unstable and prone to periodic crises. The North Korean nuclear programme has proved difficult to contain despite the use of sanctions and negotiations. Over the longer-term, the US-Sino strategic relationship is set to become one of the defining features of the global security landscape in the decades to come (see Rosecrance \& Guoling 2009). This means that while the new ways of thinking about deterrence and the mix of conventional and nuclear force in the US defence posture may at first be aimed at countering short-term security 
Accepted (pre-copy-edited) version for The Pacific Review.

threats in the region, the effect on longer-term stability between Asia's major powers cannot be ignored.

The development of North Korea's nuclear weapons programme has been one of the key factors behind Washington's current push for a greater role for advanced conventional weapons programmes (for more see Chinoy 2009). At the same time, new nuclear and non-nuclear plans being developed by Washington remain the fundamental influence on North Korea's strategic thinking (O'Neil 2007: 71). The particular irony of this bilateral relationship is that North Korea's original desire for a nuclear weapon was driven by the existence of US tactical nuclear weapons in South Korea (between 1958-1991) - a move designed to neutralise the threat of a conventional threat from the North. Yet with an increasing role for BMD and PGS in the US defence posture over the years to come, it is likely that it will instead be US conventional threats and capabilities that provide the justification for North Korea's nuclear arsenal.

Often overlooked in this regard is the commanding role of US forces in any full-scale war on the peninsula. Rather than regional adversaries such as South Korea or Japan, the United States remains so central to Pyongyang's strategic calculations as it would be a four-star American general who would take overall operational control of all forces south of the $38^{\text {th }}$ parallel once war is declared (Ibid; Harrison, 2002). ${ }^{4}$ While the North's conventional forces are quantitatively important, qualitatively they have consistently slipped behind South Korean and US forces making a small nuclear deterrent increasingly appear to be the most reliable security guarantee for Pyongyang. Official statements have outlined the specific defensive role that the North's nuclear weapons programme is meant to serve by way of deterring what they see as US aggression stating that Pyongyang will only halt the programme if Washington "drops its hostile policy towards Pyongyang and addresses its concern" (Pinkston 2003: 11). Nevertheless, as Shen Dingli points out, "To date, North Korea has virtually used the Six-Party talks to protect its nuclear development" (Dingli, 2009: 176). The furore caused by the DPRK rocket launches in April and December 2012, and particularly the third nuclear test conducted by Pyongyang in February 2013 have not helped this perception.

In contrast, despite the rhetoric about growing competition between China and the United States and the military dimensions of China's rise (see Mearshimer 2010; Holslag 2010), US-Sino strategic relations at present remain stable. China's arsenal of deliverable nuclear weapons is estimated to be around 200 (with an additional 240 warheads held in reserve) (Kile, Fechenko, Gopalaswamy \& Kristensen 2011: 340). Given the limited number of warheads available, China

\footnotetext{
${ }^{4}$ At the time of writing, the US was planning to hand over operational control to South Korea by 2015, although Seoul had requested a delay to this taking place (a previous deadline was missed in 2012).
} 
has attempted to develop its sea-based deterrent but so far has failed to achieve a major upgrade in this area. The latest research shows that its deterrent patrol is unlikely to be fully operational at present (Ibid: 341). However, the three Type 094 Jin Class submarines currently being built could mark a major change in this regard and the US Department of Defense estimates that up to five of these submarines may be eventually deployed (United States Department of Defense 2010b: 2-3).

The combination of Washington's eastward turn in defence strategy and the changes it is signaling in terms of the offence-defence balance and deterrence is likely to be central in shaping China's nuclear weapons policies in the coming years. As Taylor Fravel and Evan Medeiros have pointed out, the size of China's nuclear force and the limited roles and missions that Chinese defence planners have assigned to it are a direct product of Beijing's early embrace of the idea of deterrence through assured retaliation (Fravel \& Medeiros, 2010). In particular, China's long-held position of 'no-first-use' has historically been entirely dependent on a perception in Beijing of stable deterrence relationships with any potential nuclear rival. Yet some analysts have questioned the very foundations of this by arguing that China should consider a conventional strike on its nuclear forces and even nuclear reactors (the kind of mission that the PGS could in principle be used for) as a virtual first strike that would require nuclear retaliation (Guangqian \& Yu, 2009). Hans Kristensen has stated that "China's war-planners would have to assume that any US conventional prompt attack forces could strike without warning against their own targetable nuclear weapon forces or support installations" (quoted in Grossman, 22 August 2012). This, according to Kristensen means that "in fact, they would have to conclude that a strike against their nuclear deterrent could come before the conflict had escalated to nuclear use" (Ibid).

The importance of the role of offensive US capabilities such as PGS is compounding the existing problems associated with missile defence. Fravel and Medeiros pointed out that it is the current combination of advanced defensive and offensive capabilities that causes concern to Chinese strategists, and that together these systems are viewed in Beijing as potentially "threatening the viability of China's nuclear deterrent" (2010: 86). Such concerns were stated succinctly by Beijing after the announcement of talks between Washington and Tokyo regarding the deployment of a second long-range X-band radar at the Aomori Prefecture to bolster the regional missile defence system. China immediately released a statement saying that:

China has always believed that antimissile issues should be handled with great discretion, from the perspective of protecting global strategic stability and promoting strategic mutual trust among all countries ... we advocate avoiding the situation in which one country tries to let its own state security take priority over other countries' national security (quoted in Global Security Newswire 2012). 
Accepted (pre-copy-edited) version for The Pacific Review.

The combination of BMD and PGS offers Beijing few options in reducing nuclear weapons in its own defence posture without ceding significant ground to the United States in terms of military superiority. If part of the rationale for reducing the role of nuclear weapons in the US defence posture is to help encourage other nuclear-armed states to move towards a world free of nuclear weapons, it is difficult to see what the incentive will be for China in a nuclear disarmed world in which US conventional superiority is even greater than it is today (Futter \& Zala 2013: 113-115). Defence analysts have pointed to the development of the third generation Chinese ICBM that will be equipped with multiple independent re-entry vehicles as evidence of the extent of to which Chinese concerns over the US BMD plans are having real-world effects on Chinese defence research and development (IHS Jane's 2012; Global Security Newswire 2012a). ${ }^{5}$

The result is that a diversified deterrence strategy in the region may well appear to make sense for short-term US security against a potential North Korean hostile action, but that at the same time this strategy will cause officials in Beijing to question the reliability of the mutual deterrent relationship with Washington. In this sense, it provides a very similar paradox to the NATO strategy of balancing the Iranian threat with traditional Russian concerns in Europe (See Futter, 2011), but with two key differences: China has a much smaller nuclear arsenal than Russia, and key US allies in Europe appear less concerned with regional developments than their counterparts in Asia-Pacific. The central problem for the United States as it attempts to use "the growth of unrivalled U.S. conventional military capabilities" (United States Department of Defense 2010b: 6) and "major improvements in missile defenses" (Ibid) to reduce its reliance on nuclear weapons is that the equalising effect of nuclear weapons cannot be wished away. As a former US Secretary of Defense has admitted, "US conventional power-projection capability and the concern that it may be used to intimidate, attack or overthrow regimes" (Brown 2007: 20) is still one of the central concerns for current or potential adversaries of the United States.

\section{Nervous Allies: Japan, South Korea and Taiwan}

Taken together, these developments combine to create a second destabilising effect in the region apart from the immediate challenge of North Korea and long-term challenge of China. This is the concern of traditional US allies about the continued validity of the US security guarantee to the region. Specifically, such developments are of growing concern for Japan, South Korea and Taiwan, as each of these nations seeks to position itself in light of regional power shifts, particularly

\footnotetext{
${ }^{5}$ However it is worth noting Gregory Kulacki's point of caution in relation to reports of Chinese 'development' as opposed to 'research' in this area (2012).
} 
Accepted (pre-copy-edited) version for The Pacific Review.

the growth of Chinese power and influence. As the United States shifts its focus ever more to the region in the decades to come, the changes in its defence posture outlined above will need to be reconciled with the expectations of existing allies.

Japanese leaders are undoubtedly pleased that the US appears ready to play a much greater role in Asia-Pacific affairs, particularly in the north and east of the region, however it is less clear exactly how a renewed US conception of defence and deterrence will be received by Tokyo. As Ralph Cossa and Brad Glosserman have pointed out: "President Barack Obama's promise to seek a world free of nuclear weapons, while seemingly the realization of Japan's long-held diplomatic ambitions has intensified the contradictions and sharpened the anxieties in Tokyo" (2011: 125). These anxieties are being driven both by the ongoing tensions in the Sino-Japanese relationship as well as Pyongyang's nuclear brinkmanship (Green \& Furukawa 2008: 348). The result has become increasingly stark in public discussions about defence and security policy. As Michael Green and Katsuhisa Furukawa point out:

The rise of China and the uncertainty about long-term Chinese intentions represent the gravest strategic challenge to Japan ... The worst case scenario for these [Japanese] strategic thinkers is that increases in Chinese capabilities and decreases in US capabilities may lead the United States to conclude a bilateral arms control agreement with Beijing that endorses protection of a Chinese limited nuclear strike capability against the United States, with a decoupling effect that would be devastating for Japan (Ibid, 355).

In addition to this, North Korean and Russian nuclear forces in the region also represent a growing concern for Japan. Indeed, when taken together the concern about China's growing influence in the region and the ongoing failure to resolve the escalating North Korean crisis, has ignited a new public debate in Japan about whether it should acquire nuclear weapons (Asahi Shimbun, 2012; Japan Times 2013). While it is unlikely that Tokyo would opt to develop its own nuclear deterrent, as one account notes, "It is striking how the traditional taboo on the public discussion of nuclear options [in Japan] has weakened in recent years" (Green \& Furukawa 2008: 355-6 \& 348). Perhaps a more likely, and equally problematic route for Tokyo to take, would be the pursuit of ever-greater regional ballistic missile defence capabilities - ostensibly aimed at North Korea, but with a capability against any other potential threat (such as China) (Hughes 2013).

The second major US ally in the region, South Korea appears equally concerned about developments on its geographical doorstep. The concern regarding North Korea appears to be twofold: firstly, according to Scott Snyder, "some national security specialists, especially on the conservative end of the Korean political spectrum, worry that the narrowing of scope of the [recent US] NPR might weaken US nuclear deterrence" (Snyder 2011: 152). Indeed, concern about regional developments have already created pressure on Seoul to rethink its defence strategy, with 
Accepted (pre-copy-edited) version for The Pacific Review.

some even raising the prospect of nuclear arming their country if a negotiated solution to North's nuclear aspirations cannot be reached (Choi \& Park 2008: 373). However, and while a return to the Cold War policy of hosting US tactical nuclear weapons on Korean soil seems unlikely (Futter 2012b), and the development of an indigenous nuclear weapons capability would jeopardise South Korea's long-term goal of unification, concerns about the continued credibility of US support are mounting.

Finally, these changes have important implications for Taiwan. As Vincent Wei-Cheng Wang points out:

China's rapid military build-up since 1990 has raised the concern that the cross-Strait military balance has begun to shift in China's favour ... The military imbalance is seen as further engendering Taiwan's political survival and way of life (Wei-Cheng Wang 2008: 404).

In part because the United States will not offer an explicit guarantee to come to the aid of Taiwan's defence, "the nuclear option will always exist for a Taiwan facing existential threat from a powerful adversary", especially in the US deterrent commitment to Taiwan appears to be weakening (Ibid: 423).

Central to how the nuclear politics of the region will play out over the short-medium term is the defence posture and non-proliferation policies of the United States, as Christopher W. Hughes puts it, "... the common factor influencing and restraining all of the potential drivers for nuclear proliferation [in the region] is the stance of the United States" (Hughes 2007: 102). The challenge for the US is therefore to reassure non-nuclear allies of a credible and continuing US deterrence guarantee, respond to North Korean belligerence, while not undermining strategic relations with China. Therefore, as these two trends in US defence policy, nuanced deterrence and the AsiaPacific 'pivot' converge, a central decision is looming - whether the US-Sino strategic relationship needs to be renegotiated along more traditional lines involving mutual vulnerability on both sides, and whether this can be balanced with wider US strategic objectives for the region. This will be more difficult for Washington than Beijing, but nevertheless remains unavoidable over the longer term. Not only will the short and long-term challenges of addressing the North Korean challenge and managing the US-Sino strategic relationship be significantly affected by the shift in US deterrence thinking, but so too will the relationships with Washington's regional allies. Just as with Pyongyang and Beijing, Seoul, Tokyo and Taipei will all require answers to the inherent contradiction in a US defence posture which talks of regional stability and security assurances while ensuring its own conventional superiority well into the future. 


\section{US Policy Options: Balancing Short-term Threats and Long-term Stability}

What this suggests is that how the US addresses these 'traditional' nuclear and security related issues will have a considerable impact on the future success of the 'pivot'. There exist two important aspects to this equation. First, is the question of how regional security dynamics can be balanced with US interests (e.g. balancing a rising China, while dealing with the threat from North Korea, and maintaining solid alliances with key allies). Second, US policymakers must decide how the more specific issue of nuclear stability, non-proliferation and security fit into this view (i.e. is a continuation of a nuanced strategy to deal with North Korea really worth the larger costs of an insecure China?). Ultimately, it may be that the US has to make a choice, or at best find a balance between ensuring traditional regional stability and its more specific nuclear agenda. It would seem that three options could be considered from this point:

\section{Option 1: push ahead with a more diversified defence and deterrence strategy}

The first option available to US planners is to continue to push ahead with diversification of defence and deterrence strategy in the region. Such a policy - which has been clearly articulated as US strategy by the Obama administration - does appear to offer several immediate benefits; (1) it provides a more credible and flexible range of tools to 'deal' with the regional WMD threat posed by North Korea; (2) it feeds into the broader Obama administration strategy to reduce US reliance on nuclear weapons in security policy; (3) it offers a credible - and arguably much needed - boost to the nuclear non-proliferation regime as at least one of the five Nuclear Weapons States would be signaling some seriousness about their Article VI obligations. However, in the longer term it is possible that such a policy will become self-defeating.

There are essentially two major drawbacks of this option. First, it is not entirely clear that such a policy is commensurate with US allies' conceptions of the best means for security and stability in the region. In the words of Andrew O'Neil, "In East Asia, it seems that America's allies themselves do not see extended conventional deterrence as a credible substitute for the nuclear umbrella as part of their bilateral alliance" (O'Neil 2007: 1453). Moreover, as James Wirtz points out, nuclear weapons also play a fundamental role in underpinning broader conventional balances:

Without a robust nuclear capability, allies might become increasingly concerned that the United States will be unable to reinforce the region with conventional forces in a crisis, leading them to either strengthen their conventional capabilities or to contemplate developing their own nuclear arsenal (Wirtz 2008: 123). 
Accepted (pre-copy-edited) version for The Pacific Review.

Second, it seems very unlikely that the current drive towards a greater role for conventional weaponry in the US defence posture - regardless of whether this is part of the longer journey towards global nuclear disarmament - will be able to continue without causing major tensions with China. This is made particularly important by the 'pivot' in US defence policy in which arguments about BMD and PGS not being aimed at China are increasingly ringing hollow. The main reason behind the 'pivot' is an acceptance (however reluctant) in Washington that the growth of Chinese power, in all its different forms, has become a strategic reality that must be addressed.

Option 1 therefore appears to offer short-term security benefits to the US regarding North Korea, along with theoretical buoyancy for the nuclear non-proliferation regime, but does nothing to address the broader framework of security issues in the region. Indeed, it is not at all clear that such a policy is commensurate with either long-term security goals or nuclear non-proliferation objectives when it is considered in detail. A new arms race in non-nuclear, non-traditional weaponry would not be a good basis for stability in the region regardless of the perceived security benefits in dealing with Pyongyang.

\section{Option 2: a temporary strategic freeze}

A second, more cautious option might be to temporarily freeze the diversification of defence and deterrence strategy in the region to allow time to gauge the strategic landscape more fully before deciding how to press ahead. Such a 'wait and see' approach would buy time for strategic dialogue with China and US allies in an attempt to address some of the concerns about US conventional superiority. A freeze, particularly in the development of the PGS system and to the deployment of some aspects of BMD, would be an important symbolic move and signal willingness on the part of the United States to a serious, region-wide dialogue on strategic stability and arms control. In relation to the US-Sino relationship, this could involve specific Track II and later Track I bilateral discussions on BMD and the possibility of the current strategic arms reductions being made by Washington and Moscow being widened to include Beijing once low enough numbers are reached (for more see Cortwright \& Vayrynen 2010: 99-101). It is currently official US policy to engage in bilateral dialogue with China on strategic stability with the goal of enhancing confidence, improving transparency and reducing mistrust between the two states (United States Department of Defense 2010b: x-xi). A freeze in advanced conventional deployments would at least remove this central barrier to the success of attempts to do so.

Such a freeze would also allow for the possibility of a new region-wide push for conventional arms control negotiations. As Robert Ayson has recently noted, in this part of the 
Accepted (pre-copy-edited) version for The Pacific Review.

world, "efforts to build strong restraint through conventional arms control may be just as important as nuclear arms control itself" (Ayson 2013: 11). It is difficult to see how such efforts will succeed while Washington pursues a policy of "avoiding limitations on missile defenses and preserving options for using heavy bombers and long-range missile systems in conventional roles" (United States Department of Defense 2010b: x). Fundamentally however, as Ely Ratner points out, it is a military freeze that is required in the region in order to avoid a diplomatic freeze and John Kerry's State Department must take the lead in this (2013).

Option 2 offers a mixture of implications. On one hand a strategic freeze avoids many of the problems alluded to in option 1, but on the other it does not appear to offer any of the benefits. The result of this policy appears to be postponement of a decision rather than a making a decision in its own right, and a policy which will become inherently reactive rather than proactive, which may well end up neither reassuring allies in the region or providing a credible means to secure against North Korea and the possibility of a major crisis on the Korean Peninsula. However this option does open up the space for thinking carefully about the kinds of confidence, and eventually trust building measures that initiatives such as the Asia Pacific Leadership Network for Nuclear NonProliferation and Disarmament are now calling for (see Asia Pacific Leadership Network for NonProliferation and Disarmament 2012).

\section{Option 3: a return to traditional notions of nuclear-centric deterrence}

Lastly, the US has the option to change tack and move back towards the more traditional notions of defence and deterrence that have historically served US interests in the region (this could be done following a strategic pause to assess the region outlined in option 2). While this option looks politically unpalatable in the short-run - not least because of its implications for the Obama administration's nuclear disarmament agenda - it may offer a basis for moving towards these goals in the longer run. It may also be, considering the relative costs and problems associated with other options outlined above, that a strategy of traditional nuclear deterrence, at the very least, addresses the concerns of increasingly important actors such as China about US conventional superiority and is therefore less likely to create new crises.

Such a strategy would also appear to be acceptable to all major parties in the region; (1) it meets China's desire for a relationship based on some type of mutual vulnerability - and avoids what Robert Ross has described as a fundamental misreading of Beijing's revisionist regional agenda (2012); (2) it meets allies' expectations, especially those less enthused by moves towards non-nuclear extended deterrence who could otherwise respond by becoming new proliferators; (3) 
finally, it is probably acceptable as a status quo mechanism for North Korea. In all of these cases, it could be argued that regional stake-holders buy into the maxim that it is 'better the devil you know', at least partly because nuclear weapons and deterrence remain arguably more important in this region than almost anywhere else in the world. As Andrew O'Neil has argued; "a case can be made that nuclear weapons are likely to remain an important ingredient in East Asia's geo-strategic equation in a way they will not in other regions of the international system" (O'Neil, 2007: 1411), because if anything, "nuclear weapons are experiencing something of a revival in strategic importance in East Asia" (Ibid: 1455).

However, there are two major drawbacks to such a strategy; (1) the growing question marks over the continued validity and credibility of nuclear deterrence and MAD (Krepon 2001; OgilivieWhite 2011); (2) the impact on the international nuclear non-proliferation regime, as the consensus on the 'grand bargain' at the heart of the NPT appears to be coming under increasing pressure (Zala 2013). In this sense, it may well be that long-term regional stability and security must be privileged over short-term apparent 'wins' for the nuclear non-proliferation agenda, if the pivot is to be a successful long-term endeavour for US policy. Added to this will be a wider discussion about the long-term viability of the current approach of the Obama administration to nuclear non-proliferation and attempts to renew efforts towards global nuclear abolition. The Asia-Pacific region will be one of the key arenas in which both policy goals will need to be pursued in this century which means the key bilateral relationships discussed above must be treated in this wider context.

Ultimately - and rightly or wrongly - nuclear weapons continue to play a more prominent role in this region than the perhaps they do elsewhere in the world (see Zala 2007); this, coupled with Washington increasingly finding itself being reactive rather than proactive as it adapts to a changing global order, suggests that traditional security practices that have worked in the past have lost little of their salience in $21^{\text {st }}$ Century Asia-Pacific.

\section{Conclusion: Accepting Rather than Shaping Strategic Realities in Asia-Pacific?}

Pivoting towards the Asia-Pacific region undoubtedly offers great possibilities for the United States as it seeks to re-align itself to changing international strategic realities, and may even be the key to halting a narrative of 'decline'. But it is also a region that will provide many complex challenges; challenges that could well be exacerbated by US policy choices and actions in the near future. The current US answer to this appears to be an amalgam of traditional nuclear extended deterrence, the deployment of advanced conventional weaponry - both offensive and defensive in the region combined with rhetoric about trust building measures and engagement. This is a complicated 
combination, and it is far from clear that all US objectives can be achieved at the same time. In this sense, it could be that the US needs to make a choice about its key strategic objectives; if it is dealing with North Korea and protecting US allies in the region then relations with China may suffer. This in turn is likely to undermine the wider nuclear-non-proliferation agenda. If securing better relations with China is the key policy objective then this could leave US allies in the region feeling insecure - particularly if diplomatic approaches to North Korea fail to bear fruit - but might aid the wider nuclear non-proliferation agenda though measures such as a Fissile Material Cut-off Treaty or a Comprehensive Test Ban Treaty. Consequently - and in many ways similar to Europe the US needs to strive for a balance between short-term and long-term security requirements in the region, in the hope of pursuing a more stable and peaceful regional dynamic in the future.

However, the reality may actually be that the United States finds itself increasingly unable to decide the fate of the region, and that consequently the US may be forced to accept strategic circumstances, and react to the changing regional defence and deterrence dynamics, rather than driving through with their own preferred agenda. In this sense, it could well be that at least in the short-term a strategic freeze and even a reassertion of the role of traditional nuclear-centric deterrence is the least-worst option for US policy in the region. While this will clearly cause problems for wider nuclear non-proliferation efforts, it could - if done with care to publically accept that nuclear reductions will be done through an acceptance of mutual vulnerability and increased trust rather than unilateral conventional superiority - provide a more stable and credible basis from which future security-building discussions can be launched. In the meantime a strategy - either by design or out of necessity - which stabilises the current complex dynamics in the AsiaPacific region appears a far more sensible move than one that seeks higher goals but undermines confidence, balances and stability.

As a result, the US must play a delicate game of power politics in the region, bolstering nuclear deterrence and conventional capabilities while at the same time attempting to engage Pyongyang and build a cooperative relationship with Beijing. Achieving the confidence building measures and security guarantees necessary to accomplish these feats will clearly not be easy, but the growing importance of the region for the US, and for the wider world, means that a sustained engagement and proactive plan for stability must be at the top of Washington's agenda. Whether this is compatible with wider non-proliferation and nuclear security agenda's in the short run is questionable, but in the long run, it is possible to see a more secure region where traditional power politics and nuclear weapons play less of a role. 


\section{Bibliography}

Shimbun, Asahi. (2012) Legal Revision Agitates Japan in Nuclear-weapons Debate, 17 August, < http://ajw.asahi.com/article/behind news/politics/AJ201208170063>

Asia Pacific Leadership Network for Nuclear Non-Proliferation and Disarmament. (2012) Eliminating Nuclear Weapons Threats: A Call for New Focus and Energy from Political Leaders, Singapore, 13 September 2012, http://www.nuclearsecurityproject.org/uploads/File/Singapore\%20Statement\%20130912\%201etterhead\%20FINAL.pdf

Ayson, Robert. (2013) 'Arms Control in Asia: Yesterday's Concept for Today's Region?', Australian Journal of International Affairs 67(1): 1-17

Biden, Joe. (2013) Remarks by Vice President Joe Biden on Asia-Pacific Policy, George Washington University Washington, D.C., 19 July, The White House: Office of the Vice President, < http://www.whitehouse.gov/the-pressoffice/2013/07/19/remarks-vice-president-joe-biden-asia-pacific-policy>

Blair Dennis \& Hanley, John. (2010) 'From wheels to webs: reconstructing Asia-Pacific security arrangements', Washington Quarterly 24(1):7-17

Boulanin, Vincent. (2011) Appendix 5B: Major Arms Industry Acquisitions in Stockholm International Peace Research Institute, SIPRI Yearbook 2011: Armaments, Disarmament and International Security, Oxford and New York, Oxford University Press

Brooks, Stephen G \& Wohlforth, William C. (2008) World Out of Balance: International Relations and the Challenge of American Primacy, Princeton NJ, Princeton University Press

Brown, Harold. (2007) ‘New Nuclear Realities’ Washington Quarterly 31(1): 7-22

Bush, Richard. (2011) The US policy of extended deterrence in East Asia: history, current views and implications, Brookings Arms Control Series, Paper 5, February, http://www.brookings.edu/ /media/research/files/papers/2011/2/arms\%20control\%20bush/02_arms_control_bush.pdf ,

Chinoy, Mike (2009) Meltdown: The Inside Story of the North Korea Nuclear Crisis, New York, St Martin's Press

Choi, Kang \& Park, Joon-Sung. (2008) South Korea: fears of abandonment and entrapment”, in Alagappa, Muthiah (Eds), The Long Shadow: Nuclear Weapons and Security in $21^{\text {st }}$ Century Asia, Stanford, Stanford University Press

Cirincione, Joseph. (2000) 'Assessing the Assessment: The 1999 National Intelligence Estimate of the Ballistic Missile Threat', Nonproliferation Review, 7(1): 125-137

Clinton, Hillary Rodham. (2011) 'America’s Pacific Century', Foreign Policy, November, <http://www.foreignpolicy.com/articles/2011/10/11/americas_pacific_Century>

Copeland Dale C. (2000) The Origins of Major War, Ithaca, NY, Cornell University Press

Cordesman, Anthony. (2011) The Military Balance in Asia: 1990-2011; A Quantitative Analysis', Center for Strategic and International Studies, 16 May, http://csis.org/files/publication/110516_South_Asia-AsiaMilitaryBalance2011.pdf,

Cossa, Ralph \& Glosserman, Brad. (2011) 'Extended Deterrence and Disarmament: Japan and the New US Nuclear Posture', Nonproliferation Review 19(1): 125-145

Cox, Michael. (2011) 'Power Shift and the Death of the West?: Not Yet!', European Political Science 10(3): 416-424

Dingli, Shen. (2009) 'Cooperative Denuclearisation Toward North Korea’, Washington Quarterly 32(4): 175-188

Donilon, Tom. (2012) 'Remarks by National Security Advisor Tom Donilon: President Obama’s Asia Policy \& Upcoming Trip to Asia', 15 November, The White House: Office of the Press Secretary, < 


\section{Accepted (pre-copy-edited) version for The Pacific Review.}

http://www.whitehouse.gov/the-press-office/2012/11/15/remarks-national-security-advisor-tom-donilon-prepareddelivery>

Dunn, David H. \& Zala, Benjamin. (Forthcoming 2014) America Looks East? Transatlanticism Under the Obama Administration in Parmar, Inderjeet, Miller, Linda B., Ledwidge, Mark (eds), New Directions in US Foreign Policy, 2nd edn, London \& New York, Routledge

The Economist. (2012) 'Asia’s Balance of Power: China’s Military Rise' 7 April http://www.economist.com/node/21552212

Entous, Adam \& Barnes, Julian. (2012) ‘U.S. Plans New Asia Missile Defences’, Wall St Journal, 23 August

Florini, Ann. (2011) 'Rising Asian Powers and Changing Global Governance', International Studies Review, 13(1): 2433

Fravel, M. Taylor \& Medeiros, Evan S. (2010) 'China's Search for Assured Retaliation: The Evolution of Chinese Nuclear Strategy and Force Structure’, International Security, 35(2): 48-87

Futter, Andrew. (2011) 'Getting the Balance Right: US Ballistic Missile Defence and Nuclear Non-Proliferation', Comparative Strategy, 30(3): 254-267

Futter, Andrew (2012a) 'The Elephant in the Room: US Ballistic Missile Defence is Thriving Under Barack Obama', Defense \& Security Analysis, 28(1): 3-16

Futter, Andrew. (2012b) 'Why US Nuclear Weapons in South Korea are Not a Good Idea', nknews.org, 20 May, http://www.nknews.org/2012/05/why-u-s-nuclear-weapons-in-south-korea-are-not-a-good-idea/

Futter, Andrew. (2013) Ballistic Missile Defense and US National Security Policy, London, Routledge

Futter, Andrew \& Zala, Benjamin. (2013) 'Advanced US Conventional Weapons and Nuclear Disarmament: Why the Obama Plan Won’t Work', Non-proliferation Review, 20(1): 107-122

Global Security Newswire. (2012a) 'U.S. Missile Defense Push in Asia Seen as Response to North Korea, China', 23 August, < http://www.nti.org/gsn/article/us-desire-asian-missile-shield-seen-response-rising-china/>

Global Security Newswire. (2012b) ‘Chinese Missile Push Seeks to Counter U.S. Protections, Experts Say’, 24 August, < http://www.nti.org/gsn/article/chinese-missile-push-seeks-counter-us-protections-experts/>

Green, Michael \& Furukawa, Katsuhisa. (2008) 'Japan: New Nuclear Realism' in Alagappa, Muthiah. (Eds) The Long Shadow: Nuclear Weapons and Security in $21^{\text {st }}$ Century Asia, Stanford, Stanford University Press

Grossman, Elaine M. (2012) 'Jury Out: Do Advanced Conventional Weapons Make Nuclear War More Likely?', Global Security Newswire, 22 August, < http://www.nti.org/gsn/article/jury-out-do-advanced-conventional-weaponsmake-nuclear-war-more-likely/>

Guangqian, Peng \& Yu, Rong. (2009) 'Nuclear No-First-Use Revisited', China Security, 5(1): 78-87

Hagel, Chuck. (2013) 'Remarks by Secretary of Defense Chuck Hagel to the Malaysian Ministry of Defense, Kuala Lumpur', 25 August, U.S. Department of Defense, Office of the Assistant Secretary of Defense (Public Affairs), < http://www.defense.gov/Speeches/Speech.aspx?SpeechID=1799>

Harrison, Selig. (2002) 'Ending the Korean War', The Korean Journal of International Studies 27(1): 1-23

Hartcher, Peter (2011) 'US Marine Base for Darwin', Sydney Morning Herald, 11 November, http://www.smh.com.au/national/us-marine-base-for-darwin-20111110-1n9lk.html

Holslag, Jonathan. (2010) Trapped Giant: China's Military Rise, Abingdon, Routledge for the International Institute for Strategic Studies

Hughes, Christopher W. (2007) 'North Korea's Nuclear Weapons: Implications for the Nuclear Ambitions of Japan, South Korea and Taiwan', Asia Policy 3: 75-104 
Accepted (pre-copy-edited) version for The Pacific Review.

Hughes, Christopher W. (2013) ‘Japan, Ballistic Missile Defence and Remilitarization’, Space Policy, 29(2): 128-134

IHS Jane's. (2012) 'IHS Jane's Weapons: Strategic', 24 January, < http://www.janes.com/products/janes/defencesecurity-report.aspx? ID=1065932184>

Japan Times. 2013) 'Nuclear Arms Card for Japan', 29 April,

<http://www.japantimes.co.jp/opinion/2013/04/29/commentary/nuclear-arms-card-for-japan/>

Kile, Shannon N., Fedchenko, Vitaly., Gopalaswamy, Bharath \& Kristensen, Hans M. (2011) World Nuclear Forces in Stockholm International Peace Research Institute, SIPRI Yearbook 2011: Armaments, Disarmament and International Security, Oxford and New York, Oxford University Press

Kulacki, Gregory. (2012) 'New York Times: Distorting Chinese Press Report on Missile Capabilities?', All Things Nuclear: Insights on Science and Security, Union of Concerned Scientists, 27 August, < http://allthingsnuclear.org/newyork-times-distorting-chinese-press-report-on-missile-capabilities/>

Krepon, Michael. (2001) 'Moving Away from MAD’, Survival, 43(2): 81-95

Mahbubani, Kishore. (2008) The New Asian Hemisphere: The Irresistible Shift of Global Power to the East, New York, Public Affairs

McDonough, David. (2006) Nuclear Superiority: The New Triad and The Evolution Of Nuclear Strategy, Adelphi Paper 383, Abingdon, Routledge for the International Institute for Strategic Studies

Mearsheimer, John J. (2010) 'The Gathering Storm: China's Challenge to US Power in Asia', The Chinese Journal of International Politics 3(4): 381-396

Obama, Barack. (2009) 'Remarks by President Obama', Hradcay Square, Prague, Czech Republic, The White House Office of the Press Secretary, 5 April, http://www.whitehouse.gov/the press office/Remarks-By-President-BarackObama-In-Prague-As-Delivered/

Ogilvie-White, Tanya. (2012) On Nuclear Deterrence: The Correspondence of Sir Michael Quinlan, Adelphi Paper 421-423, London, Routledge for the International Institute for Strategic Studies

O’Neil, Andrew. (2007) Nuclear Proliferation in Northeast Asia: The Quest for Security, New York \& Houndmills, Palgrave Macmillan

Pinkston, Daniel. (2003) 'Bargaining Failure and the North Korean Nuclear Program's Impact on International Nonproliferation Regimes', KNDU Review, 8(2):11

Ratner, Ely. (2013) 'Has foggy bottom forgotten Asia?', Foreign Policy, 2 July, http://www.foreignpolicy.com/articles/2013/07/02/john_kerry_asia_pivot_middle_east

Ross, Robert. (2012) 'The Problem with the Pivot', Foreign Affairs, 91(6): 70-82

Rosecrance, Richard \& Guoliang, Gu. (2009) (Eds) Power and Restraint: A Shared Vision for the U.S. -China Relationship (New York, Public Affairs

Shanker, Thom \& Erlanger, Steven. (2012) 'U.S. Faces New Challenge of Fewer Troops in Europe', New York Times, 13 January, < http://www.nytimes.com/2012/01/14/world/europe/europe-weighs-implications-of-shrinking-us-trooppresence.html? $\mathrm{r}=0>$

Shimbun, Asahi. (2012) 'Legal Revision Agitates Japan in Nuclear-weapons Debate', 17 August, < http://ajw.asahi.com/article/behind_news/politics/AJ201208170063>. 
Synder, Scott. (2011) 'Finding a Balance Between Assurances and Abolition: South Korean Views of the Nuclear Posture', Nonproliferation Review, 19(1): 147-163

Tang, Xiaosong. (2011) 'The Future Role of the United States in the Asia-Pacific Region: Dead End or Crossroads?', Australian Journal of International Affairs, 66(5): 1-14

Tellis, Ashley J. (2010) 'Power Shift: How the West Can Adapt and Thrive in an Asian Century”, Asia Paper Series, Washington: The German Marshall Fund of the United States, http://www.gmfus.org/wpcontent/blogs.dir/1/files_mf/galleries/ct_publication_attachments/AsiaPowerShiftGMFPaper.pdf

Till, Geoffrey. (2012) Asia's Naval Expansion: An Arms Race in the Making?, Abingdon, Routledge for the International Institute for Strategic Studies

United Nations Economic and Social Commission for Asia and the Pacific. (2011) Statistical yearbook for Asia and the Pacific 2011, http://www.unescap.org/stat/data/syb2011/III-Economy/International-trade.asp

US Department of Defense. (2010a) Ballistic Missile Defense Review Report, February, http://www.defense.gov/bmdr/docs/BMDR\%20as\%20of\%2026JAN10\%200630_for\%20web.pdf

United States Department of Defense. (2010b) Nuclear Posture Review, April, http://www.defense.gov/npr/docs/2010\%20Nuclear\%20Posture\%20Review\%20Report.pdf

United States Department of Defense. (2012) Sustaining US global leadership: Priorities for $21^{\text {st }}$ Century Defense, January, https://www.documentcloud.org/documents/282223-defense-strategic-guidance.html

Wang, Vincent Wei-Cheng. (2008) 'Taiwan: Conventional Deterrence, Soft Power and the Nuclear Option' in Alagappa, Muthiah (Eds) The Long Shadow: Nuclear Weapons and Security in $21^{\text {st }}$ Century Asia, Stanford, Stanford University Press

Wesley, Michael (2011) There Goes the Neighbourhood: Australia and the Rise of Asia, Sydney, University of New South Wales Press

Woolf, Amy. (2012) Conventional prompt global strike and long-range ballistic missiles: background and issues, Congressional Research Service, 13 February, http://www.fas.org/sgp/crs/nuke/R41464.pdf

Zadra, Roberto. (2010) 'Nato, Russia and Missile Defence', The RUSI Journal 155:5: 12-16

Zala, Benjamin. (2007) ‘Asia-Pacific: The New Nuclear Fault Line?’, Security Challenges 3(1): 9-15

Zala, Benjamin. (2013) 'Can the Nuclear Non-proliferation Treaty Outrun its Double Standard Forever?', SustainableSecurity.org, August, http://sustainablesecurity.org/2013/08/02/can-the-nuclear-non-proliferation-treaty-nptoutrun-its-double-standard-forever/ 